\title{
Bio-activation of rock phosphate vis-a- vis seed treatment with phosphorus solubilizing microbes (PSM) in enhancing $P$ nutrition in cowpea and ragi
}

\author{
C.A. Kumara swamy, B.L. Raghunandan, M. Chandrashekhar and G.P. Brahmaprakash \\ Department of Agricultural Microbiology, University of Agricultural Sciences, GKVK, Bangalore-560065, India
}

raghumic2@gmail.com

\begin{abstract}
A greenhouse experiment was conducted to study bio-activation of rock phosphate vis-a-vis seed treatment with phosphorus solubilzing microbes in enhancing $\mathrm{P}$ nutrition in cowpea and ragi. Bacillus megaterium and Aspergillus awamori were used to bio-activate Udaipur rock phosphate URP and seed treatment. In both the crops higher concentration of chlorophyll was noticed when inoculated through bio-activated rock phosphate with $A$. awamori. In cowpea, more number of nodules was observed in plants inoculated through bio-activated rock phosphate with $A$. awamori. Inoculation through bio-activated rock phosphate with $B$. megaterium contained higher total $\mathrm{P}$ content and total biomass in cowpea. In ragi, total $\mathrm{P}$ content and total biomass were higher in plants inoculated through bioactivation of rock phosphate with $A$. awamori. The results indicate that inoculation of phosphorus solubilzing microbes through bio-activation of rock phosphate enhanced the phosphorus uptake and growth of cowpea and ragi.
\end{abstract}

Keywords: Rock phosphate, Bacillus megaterium, Aspergillus awamori, phosphorus solubilzing microbes.

\section{Introduction}

Phosphorus $(P)$ is an important plant nutrient required in large quantities. It is associated with several vital functions such as photosynthesis, cell division, cell organization and transfer of heredity. Phosphorus constitute about $0.2 \%$ of plant dry weight also plays a key role in crop maturity and disease resistance (Schachtman et al., 1998). Since, water soluble phosphatic fertilizers are generally fixed by iron and aluminum oxides or hydroxides in acid soils and thus, unavailable to plants. These situations necessitate searching alternative sources which are reliable and cost effective. Under such circumstances improving the availability of $P$ from the water soluble rock phosphate hold promise of higher production at a cheaper cost. Besides, the advantage of using low-grade rock phosphate as direct fertilizer, the initial crop growth and development is not normal when it is used in a non-responsive soil. There is a need to search for alternative eco-friendly sustainable systems where the supply of $P$ nutrient to plants should be ensured. Microorganisms and plants have evolved highly efficient mechanisms for absorbing Pi from very dilute solutions.

Usually the application of phosphorus solubilizing microbes (PSMs) is through seed treatment. It is well known that seed inoculation of phosphorus solubilzing microbes enhance $\mathrm{P}$ uptake and yield of economic parts (Gaur, 1990; Tomar et al., 1993). Recent studies indicated that bio-activation of rock phosphate with culture filtrates of phosphorus solubilzing microbes before application increases $\mathrm{P}$ availability soon after application and may sustain it later, since these organisms have assured supply of energy substrates. Goenadi et al. (2000) used culture filtrates of Aspergillus niger to bioactivate Mussorie rock phosphate (MRP). These findings suggested that mixing the growth media of $A$. niger with MRP caused remarkable increase in citrate soluble $P$ after incubation in laboratory. The application of bioactivated MRP with homogenized media and culture filtrate of PSMs as well as inoculation of soil with AM fungus Glomus ageratum enhances $\mathrm{P}$ uptake and growth of Leucaena and Sesbaenia (Hema, 2005). Virtually no studies have been conducted to compare the efficacy of bio-activation with seed treatment. Hence, the present study was carried out to determine better method of application of PSMs by taking cowpea and ragi as a test plants.

\section{Material and methods}

Bacillus megaterium and Aspergillus awamori, found to be most effective in solubilizing ' $P$ ' from insoluble form ' $P$ ' in laboratory investigation were used to bio-activate Udaipur rock phosphate (URP) (Table 1). These organisms were grown on modified sperber's broth in which the only source of $P$ was URP. After inoculation, flasks were incubated on temperature controlled reciprocatory shaker at $30^{\circ} \mathrm{C}$ for $15 \mathrm{~d}$. Udaipur rock phosphate was sterilized by autoclaving at $15 \mathrm{lbs} / \mathrm{sq}$. inch and at $121^{\circ} \mathrm{C}$ for $15 \mathrm{~min}$. Udaipur rock phosphate was bioactivated using culture filtrate. The culture filtrate of $B$. megaterium was obtained by centrifuging the broth at $4500 \mathrm{rpm}$ for $30 \mathrm{~min}$ and then filtering supernatant through Whatmann 42 grade filter paper. The culture filtrate of $A$. awamori was obtained by filtering the broth through Whatmann 42 grade filter paper. Udaipur rock
Research article

CIndian Society for Education and Environment (iSee)
"Bio-activation of rock phosphate" http://www.indjst.org
Kumara swamy et al. Indian J.Sci.Technol. 
phosphate was placed in conical flask. The culture filtrates were added at the rate of $50 \mathrm{ml} / \mathrm{Kg}$ of Udaipur rock phosphate. The samples were adjusted to $60 \%$ of water holding capacity by adding sterilized water. The inoculated samples were then incubated at $30^{\circ} \mathrm{C}$ for $15 \mathrm{~d}$ (Goenadi et al., 2000).

The lignite was used for the preparation of inoculants. Lignite was powdered and sieved through $200 \mathrm{~mm}$ sieve. Liming of lignite was done by mixing $\mathrm{CaCO}_{3}$ with lignite at the rate of $250 \mathrm{~g} / \mathrm{Kg}$ of lignite to raise $\mathrm{pH}$ of this mixture to 6.8 to 7 . After sieving and liming, lignite was packed into polypropylene covers at the rate of $100 \mathrm{~g}$ per pack and autoclaved at $15 \mathrm{lbs} / \mathrm{sq}$. inch and $121^{\circ} \mathrm{C}$ for $30 \mathrm{~min}$. Then broth cultures of Bacillus megaterium and Aspergillus awamori were injected to these packets separately using a sterile syringe at the rate of $20 \mathrm{ml}$ per packet and mixed uniformly.

A green house experiment was conducted to evaluate the bio-activation of rock phosphate with PSMs in enhancing $\mathrm{P}$ nutrition in cowpea (cv C-152) and ragi (cv GPU-28). Soil for conducting this study was collected from an uncultivated field at G.K.V.K, Bangalore. This soil is classified under kaolinite, isohypothermic, kanhaplustafs (SMSS technical monograph No. 19 USDA). Soil samples were sieved through $4 \mathrm{~mm}$ sieve and were mixed thourghly to get homogenous mixture. Polythene bags $(10 \times 12 \mathrm{~cm})$ were filled with $3.8 \mathrm{~kg}$ of soil. Rock phosphate was applied at the rate of $250 \mathrm{mg}$ of rock phosphate per polybag of soil. The rock phosphate applied was mixed well in the soil. The seed treatment was done separately with lignite based inoculants of $B$. megaterium and $A$. awamori at the rate of $6 \mathrm{~g} / \mathrm{kg}$ of seeds using jaggery solution as an adhesive agent. The treated seeds were dried in shade and used for sowing. The crop was harvested at 60 DAS.

The total chlorophyll content of leaves was determined on the $55^{\text {th }}$ day after sowing by the procedure outlined by Hiscox and Israelstam (1979). Shoots were harvested on 60 DAS by separating stems at the collar region. Roots were washed free of soil particles by using slow jet of water. The dry weight of shoot and root were recorded after drying in oven at $60^{\circ} \mathrm{C}$ for $72 \mathrm{~h}$ to get a constant weight. The total biomass was computed as the summation of shoot and rot dry weight. The total $P$ content in shoot and roots were determined by procedure outlined by Black (1965). The statistical analysis was done by using factorial randomized complete block design and means were separated by Duncan's multiple range test (DMRT).

\section{Results and discussion}

The phosphorus solubilzing microbes PSMs as biofertilizers in crop production is becoming popular. These PSMs have the ability of solubilzing the insoluble $P$ forms
Vol. 3 No. 7 (July 2010)

ISSN: 0974- 6846
Table 1. Treatment details (RP: Rock 1.

\begin{tabular}{|c|c|c|c|}
\multicolumn{2}{c|}{+ RP } & \multicolumn{2}{c|}{- RP } \\
\hline BM & AA & BM & AA \\
\hline 1 & 4 & 7 & 10 \\
\hline 2 & 5 & 8 & 11 \\
\hline 3 & 6 & 9 & 12 \\
\hline
\end{tabular}

(Sharma \& Kamath, 1991). Usually the application of these PSMs is through seed treatment which increases the plant growth parameters, $P$ uptake and yield of crops (Tiwari et al., 1989; Tomar et al., 1993).

Chlorophyll content

The concentration of chlorophyll in cowpea and ragi when inoculated through bio-activation and seed treatment with Bacillus megaterium and Aspergillus awamori along with and without rock phosphate was estimated. Chlorophyll concentration of cowpea plant grown through bio-activation of rock phosphate with $A$. awamori was highest $(2.25 \mathrm{mg} / \mathrm{g})$ followed by bioactivation of rock phosphate with $B$. megaterium $(2.18$ $\mathrm{mg} / \mathrm{g}$ ). The chlorophyll concentration of ragi plant grown through bio-activation of rock phosphate with $A$. awamori $(0.79 \mathrm{mg} / \mathrm{g})$ was highest followed by bio-activation of rock phosphate with $B$. megaterium $(0.74 \mathrm{mg} / \mathrm{g})$. Significant differences were observed among bio-activation and seed treatment on chlorophyll content. Inoculation with and without rock phosphate differed significantly on chlorophyll content.

Table 2. Effect of bio-activation of rock phosphate and seed treatment with $B$. megaterium and $A$. awamori with rock phosphate on total dry wt. in V. unguiculata.

\begin{tabular}{|c|c|c|c|c|c|}
\hline \multirow{3}{*}{ Treatments } & \multicolumn{4}{|c|}{ Total dry weight (g/plant) } & \multirow{3}{*}{$\begin{array}{c}\text { Main } \\
\text { effects } \\
\text { of } \\
\text { treatmen }\end{array}$} \\
\hline & \multicolumn{2}{|c|}{$+\mathrm{RP}$} & \multicolumn{2}{|c|}{ - RP } & \\
\hline & BM & AA & BM & $\mathrm{AA}$ & \\
\hline Control & $6.02^{b}$ & $6.5^{b}$ & $5.16^{b}$ & $5.46^{b}$ & $5.78^{b}$ \\
\hline Bio-activation & $9.04^{a}$ & $8.9^{a}$ & $6.8^{a}$ & $6.98^{a}$ & $7.93^{a}$ \\
\hline Seed treatment & $8.73^{a}$ & $8.34^{a}$ & $7.24^{\mathrm{a}}$ & $6.96^{a}$ & $7.82^{a}$ \\
\hline $\begin{array}{l}\text { Main effects of } \\
\text { microorganisms }\end{array}$ & \multicolumn{2}{|c|}{$\begin{array}{c}\mathrm{BM} \\
7.16^{\mathrm{a}}\end{array}$} & \multicolumn{2}{|c|}{$\begin{array}{c}\text { AA } \\
7.19^{\text {a }}\end{array}$} & - \\
\hline $\begin{array}{l}\text { Main effects of } \\
\text { rock phosphate }\end{array}$ & \multicolumn{2}{|c|}{$\begin{array}{l}+\mathrm{RP}^{\mathrm{a}} \\
7.92^{\mathrm{a}}\end{array}$} & \multicolumn{2}{|c|}{$\begin{array}{l}-\mathrm{RP} \\
6.43^{\mathrm{b}}\end{array}$} & 7 \\
\hline
\end{tabular}

RP: Rock phosphate; BM: B. megaterium; AA: A. awamori

Inoculation of PSMs through bio-activated rock phosphate increased chlorophyll content in leaves of both crops. Lebot et al. (1994) reported higher photosynthetic ability of plants inoculated with PSMs due to increased availability of phosphorus in the rhizosphere. The chlorophyll concentration has been shown to have direct connection with level of $\mathrm{P}$ and higher chlorophyll content positively correlated with net photosynthetic rate in crop plants (Ameresh \& Bhatt, 1999). Adequate supply of $P$ is essential for bio-synthesis of chlorophyll.

\section{Total biomass}

Biomass content of shoot and root as well as total biomass content of cowpea and ragi significantly increased by all the inoculated PSMs as compared to control without rock phosphate. The total dry matter content of cowpea due to bio-activation and seed treatment along with rock phosphate increased by

Research article

CIndian Society for Education and Environment (iSee)
"Bio-activation of rock phosphate" http://www.indjst.org
Kumara swamy et al. Indian J.Sci.Technol. 
Vol. 3 No. 7 (July 2010)

ISSN: 0974- 6846
Table 3. Effect of bio-activation of rock phosphate \& seed treatment with $B$. megaterium \& $A$. awamori with rock phosphate on total dry weight in E. corocana

\begin{tabular}{|c|c|c|c|c|c|}
\hline \multirow{3}{*}{ Treatments } & \multicolumn{4}{|c|}{ Total dry weight (g/plant) } & \multirow{3}{*}{$\begin{array}{c}\text { Main } \\
\text { effects } \\
\text { of } \\
\text { treatment }\end{array}$} \\
\hline & \multicolumn{2}{|c|}{$+\mathrm{RP}$} & \multicolumn{2}{|c|}{$-R P$} & \\
\hline & BM & AA & BM & AA & \\
\hline Control & $4.73^{b}$ & $4.84^{c}$ & $3.52^{c}$ & $3.6^{\mathrm{c}}$ & $4.17^{\mathrm{c}}$ \\
\hline Bio-activation & $6.98^{\mathrm{a}}$ & $7.15^{\mathrm{a}}$ & $5.61^{\mathrm{a}}$ & $5.19^{\mathrm{a}}$ & $6.23^{a}$ \\
\hline Seed treatment & $6.35^{\mathrm{a}}$ & $6.32^{b}$ & $4.87^{\circ}$ & $4.44^{\mathrm{b}}$ & $5.49^{b}$ \\
\hline $\begin{array}{l}\text { Main effects of } \\
\text { microorganisms }\end{array}$ & \multicolumn{2}{|c|}{$\begin{array}{l}\text { BM } \\
5.35^{a}\end{array}$} & \multicolumn{2}{|c|}{$\begin{array}{r}\text { AA } \\
5.25^{\text {a }}\end{array}$} & 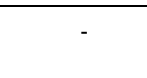 \\
\hline $\begin{array}{l}\text { Main effects of } \\
\text { rock phosphate }\end{array}$ & \multicolumn{2}{|c|}{$\begin{array}{l}+\mathrm{RP} \\
6.06^{\mathrm{a}}\end{array}$} & \multicolumn{2}{|c|}{$\begin{array}{l}-\mathrm{RP} \\
4.54^{\mathrm{b}}\end{array}$} & - \\
\hline
\end{tabular}

RP: Rock phosphate; BM: B. megaterium; $A A$ : A. awamori

$68.92 \%$ and $60.64 \%$ respectively over control without rock phosphate (Table 2). Similarly in case of ragi it increased by $107.18 \%$ and $85.77 \%$ respectively over control without rock phosphate (Table 3 ). This may be attributed to increased plant height, number of leaves and branches/plant which are the main contributing factors for plant biomass. Significant increase in total dry mater accumulation of chickpea and groundnut due to inoculation with PSMs have been reported by Gaind and Gaur (1990); Hebbara and Suseeladevi, (1990).
The increased available $P$ in the soil due to inoculation of PSMs probably increased the root biomass as $P$ is known to stimulate the growth and multiplication of plant roots. Similar reports are also available in other pulses like green gram, black gram and chick pea (Kole \& Hajra, 1999; Tanwar et al., 2003). The high dry matter production in bio-activation treatments could be attributed among other factors to the better growth of plants as well as chlorophyll content in these treatments.

\section{Total P content}

Significant increase in $\mathrm{P}$ concentration and $\mathrm{P}$ content of tissue and total $P$ uptake of cowpea and ragi inoculated through bio-activation and seed treatment in presence and absence of rock phosphate observed in current study is consistent with observations of Raj et al. (1981). Total P content of cowpea due to inoculation through bio-activation and seed treatment along with rock phosphate was increased by $391 \%$ and $352 \%$ respectively over control without rock phosphate (Table 4). Similarly in case of ragi it was by $224 \%$ and $162 \%$ respectively over control without rock phosphate (Table $5)$.

Further, seed treatment with PSMs along with rock phosphate was effective in increasing in $P$ uptake but

Table 4. Effect of bio-activation of rock phosphate and seed treatment with $B$. megaterium \& A. awamori with rock phosphate on total $P$ content in $V$. unguiculata.

\begin{tabular}{|c|c|c|c|c|c|}
\hline \multirow{3}{*}{ Treatments } & \multicolumn{4}{|c|}{ Total P content (mg/plant) } & \multirow{3}{*}{$\begin{array}{c}\text { Main } \\
\text { effects } \\
\text { of } \\
\text { treatments }\end{array}$} \\
\hline & \multicolumn{2}{|c|}{$+\mathrm{RP}$} & \multicolumn{2}{|c|}{ - RP } & \\
\hline & BM & AA & BM & AA & \\
\hline Control & $32.11^{b}$ & $31.63^{c}$ & $14.34^{b}$ & $13.54^{b}$ & $22.91^{b}$ \\
\hline Bio-activation & $68.32^{a}$ & $68.58^{a}$ & $40.9^{a}$ & $42.56^{a}$ & $55.09^{a}$ \\
\hline Seed treatment & $64.78^{a}$ & $61.32^{b}$ & $44.33^{a}$ & $41.78^{a}$ & $53.05^{a}$ \\
\hline $\begin{array}{c}\text { Main effects of } \\
\text { microorganisms }\end{array}$ & \multicolumn{2}{|c|}{$\begin{array}{c}\mathrm{BM} \\
44.13^{\mathrm{a}}\end{array}$} & \multicolumn{2}{|c|}{$\begin{array}{c}\mathrm{AA} \\
43.23^{\mathrm{a}}\end{array}$} & - \\
\hline $\begin{array}{l}\text { Main effects of } \\
\text { rock phosphate }\end{array}$ & \multicolumn{2}{|c|}{$\begin{array}{c}+\mathrm{RP} \\
54.45^{a}\end{array}$} & \multicolumn{2}{|c|}{$\begin{array}{c}-\mathrm{RP} \\
32.91^{\mathrm{b}}\end{array}$} & - \\
\hline
\end{tabular}
RP: Rock phosphate; BM: B. megaterium; AA: A. awamori

Table 5. Effect of bio-activation of rock phosphate \& seed treatment with B. megaterium \& $A$. awamori with rock phosphate on total $P$ content in E. corocana

\begin{tabular}{|c|c|c|c|c|c|}
\hline \multirow{3}{*}{ Treatments } & \multicolumn{4}{|c|}{ Total P content (mg/plant) } & \multirow{3}{*}{$\begin{array}{c}\text { Main effects } \\
\text { of } \\
\text { treatments }\end{array}$} \\
\hline & \multicolumn{2}{|c|}{$+\mathrm{RP}$} & \multicolumn{2}{|c|}{$-\mathrm{RP}$} & \\
\hline & BM & $\overline{A A}$ & BM & AA & \\
\hline Control & $26.41^{\mathrm{c}}$ & $24.83^{c}$ & $14.42^{\mathrm{C}}$ & $15.82^{b}$ & $20.37^{b}$ \\
\hline Bio-activation & $49.18^{a}$ & $48.93^{a}$ & $32.67^{a}$ & $28.49^{a}$ & $39.82^{a}$ \\
\hline Seed treatment & $40.58^{b}$ & $38.91^{b}$ & $27.72^{b}$ & $25.69^{a}$ & $33.22^{a}$ \\
\hline $\begin{array}{l}\text { Main effects of } \\
\text { microorganisms }\end{array}$ & \multicolumn{2}{|c|}{$\begin{array}{c}\text { BM } \\
31.82^{\text {a }}\end{array}$} & \multicolumn{2}{|c|}{$\begin{array}{c}\mathrm{AA} \\
30.45^{\text {a }}\end{array}$} & - \\
\hline $\begin{array}{l}\text { Main effects of } \\
\text { rock phosphate }\end{array}$ & \multicolumn{2}{|c|}{$\begin{array}{c}+\mathrm{RP} \\
38.14 \text { a }\end{array}$} & \multicolumn{2}{|c|}{$\begin{array}{l}-R P \\
24.13^{b}\end{array}$} & - \\
\hline
\end{tabular}
magnitude of increase was less than bioactivation of rock phosphate with PSMs. The higher availability of $P$ in the rhizosphere of plants inoculated through bio-activation probably induced good proliferation of root, providing enough number of sites for rhizobia to form more number of nodules and its uptake in cowpea plants. The effectiveness of legume rhizobium symbiosis is known to be improved by PSMs. Several authors also observed increased $P$ uptake in black gram, maize, Pigeonpea and soybean (Racheward et al., 1991; Dubey, 1996; Pawar \& Pawar, 1998; Kole \& Hajra, 1999). The bio-activation of rock phosphate with PSMs also enhances the plants growth parameters and nutrient uptake in Leucaena and Sesbaenia in presence and absence of AM fungi $G$. aggergatum (Hema, 2005).

From this investigation, it was observed that inoculation through bio-activation of rock phosphate with PSMs increases the crop growth. The chlorophyll content, $\mathrm{P}$ uptake and total biomass enhanced in both crops by bioactivation method of application. Hence, bioactivation of rock phosphate was the better method of application of PSMs to harness effectively phosphorus from soil.

RP: Rock phosphate; BM: Bacillus megaterium; AA: Aspergillus awamori

Research article

CIndian Society for Education and Environment (iSee)
"Bio-activation of rock phosphate" http://www.indjst.org
Kumara swamy et al. Indian J.Sci.Technol. 


\section{References}

1. Ameresh C and Bhatt RK (1999) Biochemical and physiological response to salysilic acid in relation to the systematic acquired resistance. Photosynthetica. 35, 255-258.

2. Black CA (1965) Methods of soil analysis, chemical and microbial properties. Amer. Soc. Agronomy Inc. Madison. pp:1569.

3. Dubey SK (1996) Response of soybean to rock phosphate applied with Pseudomonas striata in a tropical chemist. Ind. J. Soc. Soil. Sci. 44, 252-255.

4. Gaind SA and Gaur AC (1990) Influence of temperature on efficiency of phosphate solubilizing microorganisms. Ind. J. Microbiol. 30, 305-310.

5. Gaur AC (1990) Phosphate solubilizing microorganisms as bio-fertilizes, omega scientific publishers, New Delhi. pp:176.

6. Goenadi DH, Siswanto R and Sugiarto Y (2000) Bioactivation of poorly soluble phosphate rocks with phosphate solubilizing fungus. Soil Sci. Soc. Am. J. 64, 927-932.

7. Hebbara H and Suseeladevi L (1990) Effect of phosphate solubilizing bacteria on $\mathrm{P}$ availability to groundnut from rock phosphate. Curr. Res. 19, 56-57.

8. Hema G (2005) Phosphorus nutrition and growth of tropical tree legumes as influenced by application of bio-activated phosphate rock and mycorrhizal colonization. M.Sc. Thesis. University of Agricultural Sciences, Bangalore.

9. Hiscox JD and Israelstam GF (1979) A method for the estimation of chlorophyll from leaf tissue without maceration. Can. J. Bot. 57, 1332-1334.

10.Kole SC and Hajra JNM (1999) Mineral phosphate solubilization with reference to horticultural crops. Ind. Agriculturist. 43, 97-105.

11.Lebot T, Pilbeam DJ and Kirkby EA (1994) Plant mineral nutrition in crop production In: Mechanisms of plant growth and improved productivity modern approaches, (Ed.) Basra, A.S., Marcel Dekker, Inc. New York, pp33-72.

12.Pawar PP and Pawar VS (1998) Response of pigeon pea cv ICPL-87 to application of phosphorus and $\mathrm{P}$ solublizers. J. Maharashtra Agri. Univ. 23(2), 126128.

13. Racheward SN, Raut RS, Maleuar GU and Hasmabude AR (1991) Effect of phosphatic fertilizer on P utilization by maize. Ann. Plant Physiol. 5, 177180.

14.Schachtman DP, Reid RJ and Ayling SM (19980 Phosphorus uptake by plants: From soil to cell. Plant physiol. 166, 441-453.

15.Tanwar SPS, Sharma GL and Chahar MS (2003) Effect of phosphorus and bio-fertilizers on yield, nutrient content and uptake by black gram (Vigna mungo (L.) Hepper). Legume Res. 35, 67-76.
Vol. 3 No. 7 (July 2010)

ISSN: 0974- 6846

16.Tomar SS, Pathan A, Gupta KP and Khandkar UR (1993) Effect of PSB at different levels of phosphate on black gram. Ind. J. Microbiol. 38, 131-133. 